\title{
Atypical histopathology findings in presumed epibulbar cysticercosis
}

\author{
Brijesh Takkar, ${ }^{1}$ Garima Goel, ${ }^{2}$ Anubha Rathi, ${ }^{3}$ Mihika Dube ${ }^{1}$
}

'Ophthalmology, All india Institute of Medical Sciences, Bhopal, Madhya Pradesh, India ${ }^{2}$ Pathology, All India Institute of Medical Sciences, Bhopal, MP, India

${ }^{3}$ Dr Rajendra Prasad Centre for Ophthalmic Sciences, All India Institute of Medical Sciences, New Delhi, India

\section{Correspondence to}

Dr Anubha Rathi,

ana.aiims@gmail.com

Accepted 30 September 2018

\section{DESCRIPTION}

A 20-year-old young man presented with a painless epibulbar mass noted suddenly over the medial side of right eye (RE) 1 month back. Systemic history was insignificant and there was no history of trauma. On examination, visual acuity was $20 / 20$ in both eyes (B/E) with no limitation of ocular movements. On examination, a mass lesion measuring about $1 \mathrm{~cm}$ in its longest dimension was noted over the medial side of the RE, with no apparent compression effect (figure 1). Overlying conjunctiva was mildly oedematous and congested. The posterior extent of the mass could not be appreciated. Rest of the anterior and posterior segment examination of $\mathrm{BE}$ was within normal limits.

Ultrasound B-scan of the right orbit revealed the mass to be cystic in nature with a hyperdense echo within it, suggestive of epibulbar cysticercosis (figure 1). The cyst could not be differentiated as separate from the medial rectus. MRI showed the cyst to be $8.2 \times 4.4 \times 5.4 \mathrm{~mm}$ in size and to be closely placed near the muscle (figure 1 ). No intracranial cysts were seen. The absolute eosinophil count was found to be markedly increased to $>5000$ cells/ cumm. Hence, the patient was started on oral albendazole (400 mg two times a day) and supplemented with oral steroids $(0.5 \mathrm{mg} / \mathrm{kg})$ after 2 days. One month post initiation of treatment, the eosinophil count normalised but the mass remained the same in size as before. It had however softened, turned yellowish in colour and on repetition of ultrasound the cystic cavity was found to be full of echoes (figure 2). The patient was advised to continue the oral therapy for another 4 weeks. However, the mass did not respond further to antihelminthic therapy and the overlying conjunctiva seemed to be inflamed more than prior.

Excision biopsy was therefore advised. During surgery, the mass was found to be free from the underlying conjunctiva and the medial rectus, and

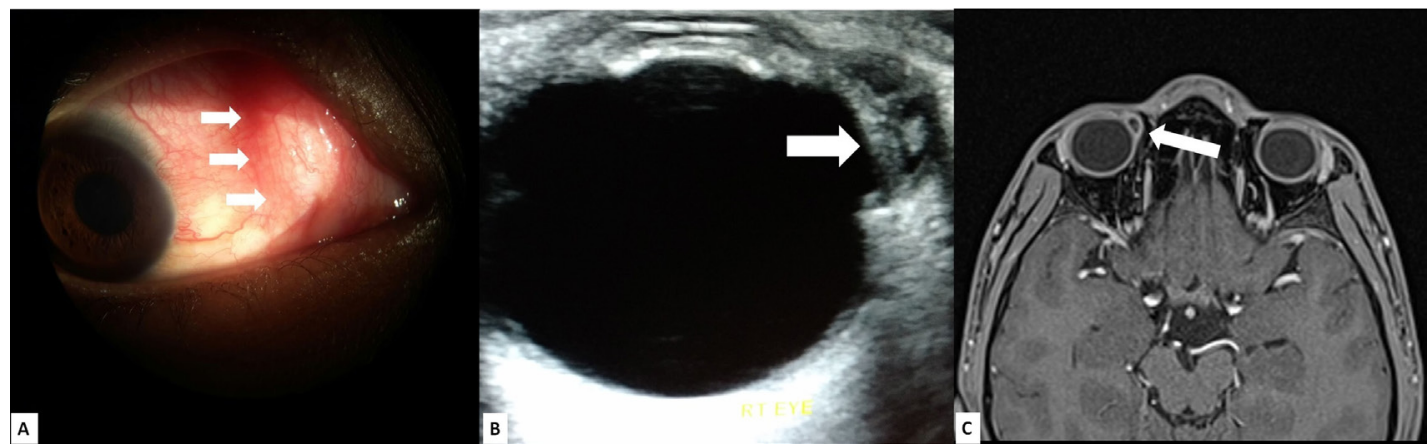

Figure 1 (A) Clinical photograph shows the epibulbar cystic lesion over medial side of the eye ball (arrows). (B) Sonography shows a cystic lesion with a hyperdense echo within its cavity that is seen as connected to the cystic wall. (C) MRI scan shows the lesion to be separate from both sclera and medial rectus, while no intracranial cysts are visible.

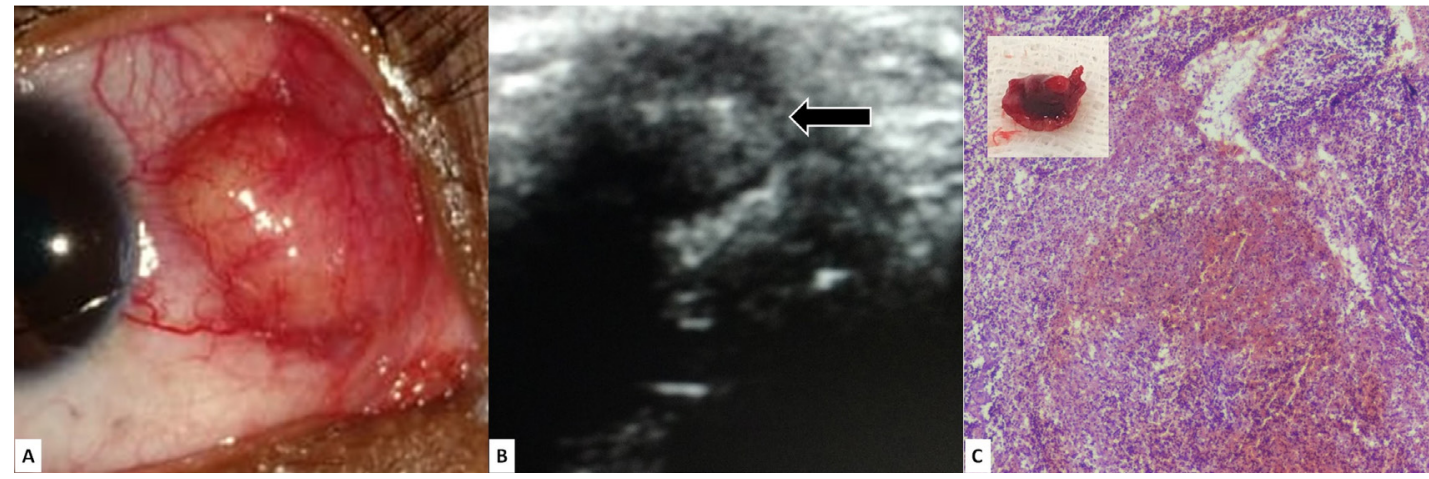

To cite: Takkar B, Goel G, Rathi $\mathrm{A}$, et al. BMJ Case Rep Published Online First: [please include Day Month Year]. doi:10.1136/bcr-2018227534

Figure 2 (A) Following antihelminthic therapy, the lesion has acquired a yellowish colour with surrounding conjunctival congestion. (B) Ultrasound done at this stage shows the lesion to be full of echoes with poorly differentiable walls (arrow). (C) Histopathological examination shows fibrocollagenous tissue with dense mixed inflammatory infiltrate including eosinophils and plasma cells. H\&E stain, magnification $\times 40$. 
could be excised in toto. The grey brown mass in gross pathological examination measured $0.8 \times 0.5 \times 0.3 \mathrm{~cm}$. Microscopic evaluation showed fibrocollagenous tissue with dense inflammatory infiltrate inclusive of eosinophils and plasma cells (figure 2). However, no evidence of parasite was seen in the biopsy specimen examined. Postoperative period was uneventful with no recurrences.

The management of intraocular cysticercosis is well defined and surgery is considered as the first line of management. ${ }^{1}$ The parasite may also lodge in extraocular sites like muscles or beneath the conjunctiva. Subconjunctival cysts are very frequently seen in close approximation with the recti muscles. Some authors have suggested conservative management for subconjunctival cysts as their natural course often involves spontaneous expulsion. However, in other circumstances, medical management may fail necessitating surgical excision, as seen in our case.

\section{Learning points}

Epibulbar cysticercosis may not respond fully to antihelminthics at times necessitating excision biopsy.

- Cases first managed with medical therapy may show inflammatory granulation tissue without definitive evidence of the parasite on histopathology.
Following excision, typical microscopic features seen include oral or intestinal parts of the cestode. ${ }^{2} 3$ However, in our case, we could see only an organised inflammatory response to the parasite on microscopy. The authors are of the view that the parasitic infection may have resolved with medical treatment leaving behind the fibrous capsule with inflammatory reaction that was revealed on histopathological examination. ${ }^{3}$

Contributors $\mathrm{BT}, \mathrm{MD}$ and $\mathrm{GG}$ worked up, imaged and diagnosed the patient. $\mathrm{BT}$ performed the surgery; GG did the microscopy; BT, GG and AR wrote the text; MD and AR critically revised the case report. BT is the overall guarantor.

Funding The authors have not declared a specific grant for this research from any funding agency in the public, commercial or not-for-profit sectors.

Competing interests None declared.

Patient consent Obtained.

Provenance and peer review Not commissioned; externally peer reviewed.

\section{REFERENCES}

1 Azad S, Takkar B, Roy S, et al. Pars plana vitrectomy with in vivo cyst lysis for intraocular cysticercosis. Ophthalmic Surg Lasers Imaging Retina 2016;47:665-9.

2 Bypareddy R, Takkar B, Chawla R, et al. Mobile subretinal cysticercus imaged by spectral-domain optical coherence tomography with motion tracker. Retin Cases Brief Rep 2018;12:272-4.

3 Dhiman R, Devi S, Duraipandi K, et al. Cysticercosis of the eye. Int I Ophthalmol 2017:10:1319-24

Copyright 2018 BMJ Publishing Group. All rights reserved. For permission to reuse any of this content visit http://group.bmj.com/group/rights-licensing/permissions.

BMJ Case Report Fellows may re-use this article for personal use and teaching without any further permission.

Become a Fellow of BMJ Case Reports today and you can:

- Submit as many cases as you like

- Enjoy fast sympathetic peer review and rapid publication of accepted articles

- Access all the published articles

Re-use any of the published material for personal use and teaching without further permission

For information on Institutional Fellowships contact consortiasales@bmjgroup.com

Visit casereports.bmj.com for more articles like this and to become a Fellow 